\title{
ANALISIS YURIDIS \\ DEGRADASI KEKUATAN PEMBUKTIAN DAN PEMBATALAN \\ AKTA NOTARIS MENURUT PASAL 84 UNDANG-UNDANG \\ NOMOR 30 TAHUN 2004 TENTANG JABATAN NOTARIS
}

\author{
Idris Aly Fahmi
}

\author{
CV. Pribumi Sejahtera \\ J1. Ciwulan 17 A Malang \\ Email: idrisalifahmi55@gmail.com
}

\begin{abstract}
The objectives of this journal are to describe and to analyze the boundary of the degraded verifying strength and the boundary of the cancellation of Notary Public Certificate based on Article 84 Act No.30 of 2004 about The Rank of Notary Public, and also to describe and to analyze the mechanism of the application of civil sanction against Notary Public in the case of the degraded verifying strength and the cancellation of Notary Public Certificate. Method used in this journal is normative juridical with statute and conceptual approaches. Result of research indicates that the boundary of Notary Public Certificate with degraded verifying strength into a merely under-hand document is when Notary Public Certificate has violated Article 16 Verse (1) Letter l, Article 16 Verse (7), Article 16 Verse (8), Article 41 with reference to Article 39 and 40, and Article 52 of Act No. 30 of 2004 about The Rank of Notary Public. The boundary of the cancellation, or being cancelled based on law, pursuant to Article 84 of Act No.30 of 2004 about The Rank of Notary Public, is when Notary Public Certificate deviates from what has been stated in Article 16 Verse (1) Letter i, Article 16 Verse (1) Letter k, Article 44, Article 48, Article 50, and Article 51 of Act No.30 of 2004 about The Rank of Notary Public. The mechanism of the application of civil sanction against Notary Public is decided through the court process begun with the allegation by the parties in the certificate who is adversely affected due to the mistake or the negligence of Notary Public which is considered as violating Article 84 of Act No.30 of 2004 about The Rank of Notary Public, and/or contravening against the provision of Article 1865 of Civil Code.
\end{abstract}

Key words: degradation, verifying strength, cancellation, notary public certificate

\begin{abstract}
Abstrak
Tujuan dari penulisan jurnal ini adalah untuk mendeskripsikan dan menganalisis batasan degradasi kekuatan pembuktian dan batasan pembatalan akta Notaris menurut ketentuan Pasal 84 Undang-undang Nomor 30 Tahun 2004 Tentang Jabatan Notaris, dan untuk menganalisis mekanisme penerapan sanksi perdata terhadap Notaris dalam hal terjadinya degradasi kekuatan pembuktian atau pembatalan akta Notaris. Metode penelitian yang digunakan dalam penulisan jurnal ini adalah penelitian yuridis normatif dengan pendekatan perundang-undangan, dan pendekatan konseptual. Berdasarkan hasil penelitian, batasan akta Notaris yang terdegradasi kekuatan pembuktiannya menjadi akta di bawah tangan adalah akta Notaris yang melanggar
\end{abstract}


ketentuan Pasal 16 ayat (1) huruf1, Pasal 16 ayat (7), Pasal 16 ayat (8), Pasal 41 dengan menunjuk ketentuan Pasal 39 dan Pasal 40, serta melanggar ketentuan Pasal 52 Undang-undang Nomor 30 Tahun 2004 Tentang Jabatan Notaris. Sementara batasan akta Notaris yang mengalami pembatalan atau batal demi hukum menurut Pasal 84 Undang-undang Nomor 30 Tahun 2004 Tentang Jabatan Notaris adalah melanggar kewajiban sebagaimana disebutkan dalam Pasal 16 ayat (1) huruf i, Pasal 16 ayat (1) huruf k, Pasal 44, Pasal 48, Pasal 50, dan Pasal 51 Undangundang Nomor 30 Tahun 2004 Tentang Jabatan Notaris. Mekanisme penerapan sanksi perdata terhadap Notaris dijatuhkan melalui proses peradilan yang diawali oleh gugatan para pihak dalam akta yang merasa dirugikan akibat kesalahan atau kelalaian Notaris yang melanggar ketentuan pasal 84 Undang-undang Nomor 30 Tahun 2004 Tentang Jabatan Notaris sebagaimana diatur dalam ketentuan Pasal 1865 KUHPerdata dan sejalan dengan teori pembuktian.

Kata kunci: degradasi, kekuatan pembuktian, pembatalan, akta notaris

\section{Latar Belakang}

Undang-Undang Dasar Negara Republik Indonesia Tahun 1945 menyebutkan dengan tegas, bahwa Indonesia adalah negara hukum. Prinsip dari negara hukum adalah menjamin kepastian, ketertiban dan perlindungan hukum yang berintikan kebenaran dan keadilan. Kepastian, ketertiban dan perlindungan hukum menuntut adanya alat bukti yang menentukan dengan jelas hak dan kewajiban orang atau badan hukum sebagai subjek hukum di dalam masyarakat. ${ }^{1}$

Dalam hukum Perdata dikenal beberapa alat bukti, sebagaimana telah ditentukan dalam Pasal 1866 KUH Perdata yang meliputi, bukti tulisan, bukti dengan saksisaksi, persangkaan-persangkaan, pengakuan, dan sumpah. Pembuktian dengan tulisan dilakukan dengan akta otentik maupun dengan akta di bawah tangan. Akta adalah suatu tulisan yang memang dengan sengaja dibuat untuk dapat dijadikan bukti bila ada suatu peristiwa dan ditanda tangani ${ }^{2}$. Akta memiliki 2 (dua) fungsi penting, yaitu fungsi formil (formalitas causa) dan fungsi alat bukti (probationis causa). Fungsi formil (formalitas causa) berarti bahwa untuk lengkapnya atau sempurnanya (bukan untuk sahnya) suatu perbuatan hukum haruslah dibuat suatu akta. Fungsi alat bukti (probationis causa) bahwa akta itu dibuat sejak semula dengan sengaja untuk pembuktian di kemudian hari, sifat tertulisnya suatu perjanjian dalam bentuk akta itu tidak membuat sahnya perjanjian, tetapi hanyalah agar dapat digunakan sebagai alat bukti dikemudian hari. ${ }^{3}$

Akta di bawah tangan adalah akta yang dibuat dalam bentuk yang tidak ditentukan oleh undang-undang, tanpa perantara atau tidak di hadapan Pejabat Umum yang berwenang, sedangkan akta otentik adalah akta yang di dalam bentuk yang ditentukan

1 Jimly Asshiddiqie dan Ali Safa'at, Teori Hans Kelsen Tentang Hukum, Setjen dan Kepaniteraan Mahkamah Konstitusi Republik Indonesia, Jakarta, 2006, hlm. 61.

2 R. Subekti, Hukum Pembuktian, Pradinya Paramita, Jakarta, 2001, hlm. 48.

3 Sudikno Mertokusumo, Mengenal Hukum suatu Pengantar, Liberty, Yogyakarta, 1999, hlm.121-122. 
oleh undang-undang dibuat oleh atau di hadapan pejabat umum yang berwenang untuk itu di tempat dimana akta itu dibuat. Baik akta otentik maupun akta di bawah tangan dibuat sejatinya untuk dipergunakan sebagai alat bukti. Perbedaan yang penting antara kedua jenis akta tersebut adalah dalam hal nilai pembuktiannya. Akta otentik memiliki kekuatan pembuktian sempurna, lengkap, dan telah mencukupi batas minimal alat bukti yang sah tanpa lagi diperlukan alat bukti lain dalam suatu sengketa hukum perdata, sedangkan akta di bawah tangan mempunyai kekuatan pembuktian sepanjang para pihak mengakuinya atau tidak ada penyangkalan dari salah satu pihak.

Pasal 1868 KUH Perdata merupakan sumber untuk otensitas akta Notaris dan juga sebagai dasar legalitas eksistensi akta Notaris. Pasal 1868 KUH Perdata hanya merumuskan arti kata otentik dan tidak menyebutkan siapa pejabat umum itu, bagaimana bentuk aktanya dan kapan Pejabat Umum itu berwenang. Secara implisit pasal ini menghendaki adanya suatu Undang-undang yang mengatur tentang Pejabat Umum dan bentuk aktanya. Undangundang Nomor 30 Tahun 2004 tentang Jabatan Notaris atau biasa disebut dengan UUJN merupakan satu-satunya Undang-undang organik yang mengatur Notaris sebagai Pejabat Umum dan bentuk akta Notaris. Notaris menurut UUJN adalah pejabat umum yang berwenang untuk membuat akta otentik dan kewenangan lainnya sebagaimana dimaksud dalam Undang-undang. Notaris merupakan perpanjangan tangan dari Pemerintah dalam hal ini negara. Negara telah memberikan kepercayaan kepada Notaris untuk menjalankan sebagian urusan atau tugas negara, khususnya dalam bidang hukum perdata.

Notaris oleh undang-undang diberi wewenang untuk menuangkan semua perbuatan, perjanjian, dan penetapan yang dikehendaki oleh para pihak yang sengaja datang ke hadapan Notaris untuk mengakomodasi keterangan itu dalam suatu akta otentik, dan agar akta yang dibuatnya memiliki kekuatan bukti yang lengkap dan memiliki keabsahannya. Notaris bukan semata-mata sebagai juru tulis, namun Notaris juga perlu mengkaji apakah yang diinginkan para penghadap untuk dinyatakan dalam akta otentik tidak bertentangan dengan UUJN dan aturan hukum lain yang berlaku. Kewajiban untuk mengetahui dan memahami syaratsyarat otentisitas, keabsahan dan sebab-sebab kebatalan suatu akta Notaris sangat penting untuk menghindari adanya cacat hukum yang dapat mengakibatkan terdegradasinya kekuatan pembuktian akta Notaris dan batalnya akta Notaris, dimana hal tersebut akan merugikan kepentingan masyarakat, terutama pihak-pihak yang berkepentingan.

Degradasi sendiri diartikan sebagai penurunan tentang pangkat, mutu, moral, kemerosotan, kemunduran, atau dapat juga menempatkan ditingkat yang lebih rendah ${ }^{4}$.

4 Kementerian Pendidikan Nasional, Kamus Besar Bahasa Indonesia Pusat Bahasa Edisi Keempat, Gramedia Pustaka Utama, Jakarta, 2008, hlm. 304. 
Sementara pembatalan adalah proses, cara, atau perbuatan membatalkan sesuatu. Dalam kaitannya dengan akta Notaris, istilah terdegradasi terjadi manakala akta Notaris sebagai akta otentik yang memiliki kekuatan bukti sempurna dan mengikat, serta telah mencukupi batas minimal alat bukti yang sah tanpa lagi diperlukan alat bukti lain dalam sengketa hukum Perdata mengalami kemunduran, kemerosotan, atau penurunan mutu dalam arti posisinya lebih rendah dalam kekuatan sebagai alat bukti lengkap dan sempurna menjadi permulaan pembuktian seperti akta di bawah tangan dan memiliki cacat hukum yang menyebabkan pembatalan atau ketidakabsahannya akta Notaris tersebut. ${ }^{5}$

Sehubungan dengan terdegradasinya kekuatan pembuktian dan pembatalan akta Notaris, Pasal 84 UUJN menyebutkan bahwa :"Tindakan pelanggaran yang dilakukan oleh Notaris terhadap ketentuan sebagaimana dimaksud dalam Pasal 16 ayat (1) huruf i, Pasal 16 ayat (1) huruf k, Pasal 41, Pasal 44, Pasal 48, Pasal 49, Pasal 50, Pasal 51, atau Pasal 52 yang mengakibatkan suatu akta hanya mempunyai kekuatan pembuktian sebagai akta di bawah tangan atau suatu akta menjadi batal demi hukum dapat menjadi alasan bagi pihak yang menderita kerugian untuk menuntut penggantian biaya, ganti rugi, dan Bunga kepada Notaris".

Pasal 84 UUJN ini mengatur mengenai sanksi Perdata yang dikenakan terhadap Notaris dimana sanksi tersebut berkaitan dengan akta yang dibuat di hadapan atau oleh Notaris. Ada dua hal penting yang perlu dicermati mengenai sanksi yang diatur dalam Pasal 84 UUJN. Pertama, Pasal 84 UUJN tidak mengatur mengenai mekanisme atau tata cara tertentu untuk menerapkan sanksi yang dimaksud. Dalam Pasal 84 UUJN disebutkan bahwa akta Notaris yang tidak memenuhi syarat sebagaimana telah ditentukan menjadi akta yang mempunyai kekuatan pembuktian sebagai akta di bawah tangan atau menjadi batal demi hukum, tanpa menyebutkan tata cara penerapan sanksi perdata terhadap Notaris, yang berarti akta tersebut serta merta menjadi akta di bawah tangan atau batal demi hukum tanpa perlu dibuktikan terlebih dahulu. Jika dicermati lebih jauh, substansi Pasal 84 UUJN ini dapat dibandingkan dengan Pasal 60 Peraturan Jabatan Notaris (PJN) yang termuat dalam Reglement op Het Notaris Ambt in Indonesia (Stbl. 1860:3), dimana dalam Pasal 60 PJN disebutkan jika akta yang dibuat di hadapan Notaris tidak memenuhi syarat bentuk dapat dibatalkan di muka pengadilan atau dianggap hanya dapat berlaku sebagai akta yang dibuat di bawah tangan. Menurut Pasal 60 PJN dalam pembatalan akta untuk berlaku sebagai akta di bawah tangan

5 Sjaifurrachaman, Aspek Pertanggungjawaban Notaris Dalam Pembuatan Akta, Mandar Maju, Bandung, 2011, hlm. 122. 
memerlukan putusan pengadilan, sementara dalam Pasal 84 UUJN tidak menyebutkan mekanisme seperti yang diatur dalam Pasal 60 PJN.

Hal kedua yang perlu dicermati terkait isi dari Pasal 84 UUJN adalah dimana Pasal ini tidak memberikan batasan yang jelas dan tegas mengenai akta Notaris yang memiliki kekuatan pembuktian di bawah tangan dan akta yang menjadi batal demi hukum. Pasal 84 UUJN justru mencampuradukkan kedua hal tersebut dan menentukan batasannya secara alternatif dengan menggunakan kata "atau" pada kalimat :

“...mengakibatkan suatu akta hanya mempunyai kekuatan pembuktian sebagai akta di bawah tangan atau suatu akta menjadi batal demi hukum ..."

Istilah akta di bawah tangan dan akta yang batal demi hukum adalah dua hal yang berbeda dan memiliki akibat hukum yang berbeda. Istilah akta di bawah tangan berkaitan dengan nilai pembuktian suatu alat bukti. Akta di bawah tangan mempunyai kekuatan pembuktian sepanjang isi dan tandatangan yang tercantum di dalamnya diakui oleh para pihak. ${ }^{6}$ Jika salah satu pihak mengingkarinya, maka nilai pembuktian tersebut diserahkan kepada hakim. Sementara itu istilah batal demi hukum merupakan istilah yanag biasa dipergunakan untuk menilai suatu perjanjian jika tidak memenuhi syarat objektif sebagaimana ditentukan dalam Pasal 1320 KUHPerdata.

Sebagai sebuah aturan yang mengatur mengenai sanksi Perdata terhadap Notaris, Pasal 84 UUJN tidak memberikan batasan yang jelas dan tegas terhadap sanksi serta tidak memberikan mekanisme penerapan sanksi. Isi Pasal 84 UUJN ini menjadi kabur sebagai sebuah peraturan jika melihat ketentuan dari Pasal 5 Undang-undang Nomor 12 Tahun 2011 tentang Pembentukan Peraturan Perundangundangan yang menyebutkan bahwa :

Dalam membentuk peraturan perundangundangan harus dilakukan berdasarkan pada asas pembentukan peraturan perundangundangan yang baik, yang meliputi (a) kejelasan tujuan, (b) kelembagaan atau pejabat yang tepat, (c) kesesuaian antara jenis, hierarki, dan materi muatan, (d) dapat dilaksanakan, (e) kedayagunaan dan kehasilgunaan, (f) kejelasan rumusan, (g) keterbukaan.

Pasal 84 UUJN menurut penulis tidak memenuhi asas kejelasan rumusan sebagaimana telah diatur dalam ketentuan Pasal 5 Undang-undang Nomor 12 Tahun 2011 tentang Pembentukan Peraturan Perundang-undangan. Kejelasan rumusan menurut penjelasan Undang-undang Nomor 12 Tahun 2011 tentang Pembentukan Peraturan Perundang-undangan adalah bahwa setiap peraturan perundang-undangan harus memenuhi persyaratan teknis penyusunan peraturan perundang-undangan, sistematika dan pilihan kata atau terminologi serta bahasa

6 Habib Adjie, Hukum Notaris Indonesia, Refika Aditama, Jakarta, 2009, hlm. 203. 
hukumnya jelas dan mudah dimengerti sehingga tidak menimbulkan berbagai macam interpretasi dalam pelaksanaannya.

Berdasarkan uraian di atas, permasalahan yang diangkat dalam penulisan jurnal ini adalah bagaimana batasan degradasi kekuatan pembuktian dan pembatalan akta Notaris serta bagaimana mekanisme penerapan sanksi perdata terhadap Notaris dalam hal terjadinya degradasi kekuatan pembuktian atau pembatalan akta Notaris.

Jenis penelitian yang digunakan dalam penelitian ini adalah yuridis normatif (normative legal research). Pendekatan yang digunakan dalam penelitian ini adalah pendekatan perundang-undangan (statute approach), dan pendekatan konseptual (conceptual approach). Pendekatan perundang-undangan digunakan dalam penelitian ini sebagai dasar melakukan analisis terhadap berbagai ketentuan peraturan perundang-undangan yang terkait dengan batasan degradasi kekuatan pembuktian dan pembatalan akta Notaris serta mekanisme penerapan sanksi perdata terhadap Notaris. Pendekatan konseptual dengan menggunakan pandangan-pandangan dan doktrin-doktrin yang berkembang di dalam ilmu hukum serta melahirkan ide, konsep, serta asas hukum yang relevan dengan permasalahan yang diteliti.

Bahan hukum yang digunakan dalam penulisan ini adalah dengan bahan hukum primer yang berupa peraturan perundangundangan, bahan hukum sekunder yang terdiri dari buku teks, jurnal hukum, bahan hukum tersier yaitu bahan hukum yang memberikan petunjuk maupun penjelasan tentang bahan hukum primer dan bahan hukum sekunder, seperti kamus istilah hukum.

Bahan-bahan hukum yang telah dikumpulkan, peneliti uraikan, dideskripsikan secarakualitatifuntuk menjawab permasalahan yang sedang diteliti. Pengolahan bahan hukum dilakukan secara deduktif, yakni menarik kesimpulan dari permasalahan yang bersifat umum terhadap permasalahan kongkrit yang diteliti. Selanjutnya bahan hukum yang ada dianalisis dengan mengaitkan bahan hukum yang lain. Bahan hukum yang dianalisis dengan menggunakan metode interpretasi gramatikal (menurut bahasa) yakni menafsirkan katakata dalam undang-undang sesuai dengan kaidah bahasa dan kaidah hukum tata bahasa. ${ }^{7}$ Kemudian dilakukan pemecahan masalah diteliti dengan cara memaparkan bahan hukum yang telah diperoleh dari studi pustaka dan undang-undang dianalisis dalam bentuk kesimpulan.

\section{Pembahasan}

\section{A. Konsep Degradasi Kekuatan Pembuktian dan Pembatalan Akta Notaris}

Menurut Kamus besar Bahasa Indonesia, kata degradasi mempunyai arti penurunan, tentang pangkat, mutu, moral dan sebagainya, kemunduran, kemerosotan atau dapat juga menempatkan ditingkat yang lebih rendah. 
Sementara itu, pembatalan adalah proses, cara, atau perbuatan membatalkan sesuatu. Dalam kaitannya dengan akta Notaris, istilah terdegradasi terjadi manakala akta Notaris sebagai akta otentik yang memiliki kekuatan bukti sempurna dan mengikat, serta telah mencukupi batas minimal alat bukti yang sah tanpa lagi diperlukan alat bukti lain dalam sengketa hukum Perdata mengalami kemunduran, kemerosotan, atau penurunan mutu dalam arti posisinya lebih rendah dalam kekuatan sebagai alat bukti lengkap dan sempurna menjadi permulaan pembuktian seperti akta di bawah tangan dan memiliki cacat hukum yang menyebabkan pembatalan atau ketidakabsahannya akta Notaris tersebut.

Degradasi kekuatan pembuktian akta Notaris dapat terjadi apabila dalam pembuatannya terjadi pelanggaran terhadap ketentuan persyaratan berdasarkan hukum yang berlaku. Beberapa contoh hal yang mengakibatkan terdegradasinya akta Notaris adalah, pembuatan akta-akta yang tidak sesuai dengan fakta, Notaris dalam membuat akta tidak menjamin kebenaran formil atas akta tersebut, para pihak tidak menghadap kepada Notaris, akta yang dibuat tidak dibacakan oleh Notaris kepada penghadap dan saksi-saksi, dan akta tidak ditandatangani pada tanggal yang sama oleh para penghadap. ${ }^{8}$ Dalam jurnal ini istilah degradasi kekuatan pembuktian akta Notaris difokuskan terhadap perubahan status akta Notaris sebagai akta otentik yang memiliki kekuatan pembuktian lengkap dan sempurna serta memiliki kekuatan mengikat, mengalami penurunan mutu, kemunduran, atau kemerosotan status dalam arti posisinya lebih rendah dalam hal pembuktian. Akta tersebut mengalami penurunan posisi dari kekuatan bukti lengkap dan sempurna menjadi permulaan pembuktian sebagaimana disebut sebagai akta di bawah tangan.

Sementara itu penerapan istilah pembatalan akta Notaris dalam jurnal ini dikaitkan dengan istilah batal demi hukum (nietig) dimana hal tersebut berkaitan dengan yang biasa digunakan untuk menilai suatu perjanjian jika tidak memenuhi syarat objektif, yaitu suatu hal tertentu (een bepaald onderwerp) dan sebab yang tidak dilarang (een geoorloofde oorzaak). Terkait dengan istilah batal demi hukum tentu tidak akan lepas dengan isi ketentuan dari Pasal 1320 KUHPerdata yang mengatur mengenai syaratsyarat sahnya perjanjian pada umumnya, dimana hal tersebut meliputi, (a) sepakat mereka yang mengikatkan diri, (b) kecakapan membuat suatu perjanjian, (c) suatu hal tertentu, (d) kausa halal atau tidak terlarang.

Ketentuan pasal 1320 KUHPerdata bersifat kumulatif, artinya setiap perjanjian harus memenuhi keempat persyaratan tersebut secara bersama-sama. ${ }^{9}$ Tidak dipenuhinya salah satu syarat dalam ketentuan Pasal 1320 KUHPerdata tersebut mengakibatkan perjanjian menjadi cacat hukum yang

8 Sjaifurrachaman, op cit.

9 Mariam Darus Badrulzaman, Kompilasi Hukum Perikatan, Citra Aditya Bakti, Bandung, 2001, hlm. 66. 
keabsahannya dapat dipertanyakan dalam arti dapat batal atau dapat dibatalkan oleh pihak ketiga yang berkepentingan. Syarat (a) dan (b) dalam ketentuan Pasal 1320 KUHPerdata merupakan syarat subjektif, hal ini dikarenakan berhubungan dengan orang-orang atau subjek yang mengadakan perjanjian. Jika syarat subjektif ini dilanggar, maka perjanjian tersebut dapat dibatalakan. Syarat (c) dan (d) dalam ketentuan Pasal 1320 KUHPerdata merupakan syarat objektif, hal ini dikarenakan berkaitan dengan isi dari perjanjian. Jika syarat objektif ini dilanggar maka perjanjian tersebut menjadi batal demi hukum.

\section{B. Batasan Akta Notaris yang Memiliki Kekuatan Pembuktian sebagai Akta di Bawah Tangan}

Akta di bawah tangan adalah akta yang dibuat dalam bentuk yang tidak ditentukan oleh undang-undang, tanpa perantara atau tidak di hadapan Pejabat Umum yang berwenang. Pengertian dari akta di bawah tangan ini dapat diketahui dari Pasal 101 ayat b Undang-Undang No. 5 Tahun 1986 Tentang Peradilan Tata Usaha Negara, menyatakan bahwa akta di bawah tangan, yaitu surat yang dibuat dan ditandatangani oleh pihakpihak yang bersangkutan dengan maksud untuk dipergunakan sebagai alat bukti tentang peristiwa atau peristiwa hukum yang tercantum di dalamnya. Selain itu, definisi dari akta di bawah tangan juga dapat dilihat dalam ketentuan Pasal 1874 Kitab UndangUndang Hukum Perdata, menyatakan bahwa yang dianggap sebagai tulisan di bawah tangan adalah akta yang ditandatangani di bawah tangan, surat, daftar, surat urusan rumah tangga dan tulisan-tulisan yang lain yang dibuat tanpa perantaraan seorang pejabat umum.

Untuk menentukan akta Notaris yang mempunyai kekuatan pembuktian sebagai akta di bawah tangan dapat dilihat dan ditentukan dari isi (dalam) pasal-pasal tertentu yang menegaskan secara langsung jika Notaris melakukan pelanggaran, maka akta yang bersangkutan termasuk akta yang mempunyai kekuatan pembuktian sebagai akta di bawah tangan. Jika tidak disebutkan dengan tegas dalam pasal yang bersangkutan sebagai akta yang mempunyai kekuatan pembuktian sebagai akta di bawah tangan, maka pasal lainnya yang dikategorikan melanggar menurut Pasal 84 UUJN termasuk ke dalam akta yang batal demi hukum. ${ }^{10}$

Pasal 1869 KUHPerdata menentukan batasan akta Notaris yang mempunyai kekuatan pembuktian sebagai akta di bawah tangan jika tidak memenuhi beberapa syarat sebagaimana berikut : (a) tidak berwenangnya pejabat umum yang bersangkutan, (b) tidak mampunya pejabat umum yang bersangkutan, dan (c) cacat dalam bentuknya. Sehubungan dengan terdegradasinya kekuatan pembuktian 
akta Notaris dari akta otentik menjadi akta di bawah tangan, Pasal 84 UUJN menyebutkan bahwa :

"Tindakan pelanggaran yang dilakukan oleh Notaris terhadap ketentuan sebagaimana dimaksud dalam Pasal 16 ayat (1) huruf i, Pasal 16 ayat (1) huruf k, Pasal 41, Pasal 44, Pasal 48, Pasal 49, Pasal 50, Pasal 51, atau Pasal 52 yang mengakibatkan suatu akta hanya mempunyai kekuatan pembuktian sebagai akta di bawah tangan atau suatu akta menjadi batal demi hukum dapat menjadi alasan bagi pihak yang menderita kerugian untuk menuntut penggantian biaya, ganti rugi, dan Bunga kepada Notaris"

Dalam beberapa pasal yang terkandung dalam ketentuan pasal 84 UUJN tersebut di atas ada beberapa pasal yang mengatur atau menyebutkan secara tegas bahwa pelanggaran terhadap ketentuan pasal-pasal tertentu mengakibatkan akta otentik yang dibuat oleh Notaris mengalami degradasi atau penurunan status menjadi akta di bawah tangan. Adapun pasal-pasal tersebut meliputi : (a) melanggar ketentuan Pasal 16 ayat (1) huruf 1, yaitu tidak membacakan akta di hadapan penghadap dengan dihadiri oleh paling sedikit 2 (dua) orang saksi dan ditandatangani pada saat itu juga oleh penghadap, saksi, dan Notaris, (b) melanggar ketentuan Pasal 16 ayat (7) dan ayat (8), yaitu jika Notaris pada akhir akta tidak mencantumkan kalimat bahwa para penghadap menghendaki agar akta tidak dibacakan karena penghadap membaca sendiri, mengetahui, dan memahami isi akta, (c) melanggar ketentuan
Pasal 41 dengan menunjuk kepada Pasal 39 dan Pasal, dan (d) melanggar ketentuan Pasal 52, yaitu membuat akta untuk diri sendiri, istri atau suami, atau orang lain yang mempunyai hubungan kekeluargaan dengan Notaris, baik karena perkawinan maupun hubungan darah dalam garis keturunan lurus ke bawah dan/ atau ke atas tanpa pembatasan derajat, serta dalam garis ke samping sampai dengan derajat ke tiga, serta menjadi pihak untuk diri sendiri, maupun dalam suatu kedudukan ataupun dengan perantaraan kuasa.

Jika melihat klasifikasi atau batasan sebagaimana disebutkan dalam Pasal 1869 KUHPerdata, maka pasal-pasal tersebut yang terkandung dalam pasal 84 UUJN yang menegaskan pelanggaran terhadap ketentuan tersebut mengakibatkan akta Notaris mempunyai kekuatan pembuktian sebagai akta di bawah tangan, dapat dianalisis sebagai berikut: (1) Pasal 16 ayat (1) huruf 1 dan Pasal 16 ayat (7) dan ayat (8) termasuk kedalam cacat bentuk akta Notaris, karena pembacaan akta oleh Notaris di hadapan para pihak dan saksi merupakan suatu kewajiban untuk menjelaskan bahwa akta yang dibuat tersebut sesuai dengan kehendak yang bersangukutan, dan setelah dilakukan pembacaan tersebut wajib dicantumkan pada bagian akhir akta Notaris. Demikian pula jika Notaris tidak membacakan di hadapan para pihak, tapi para pihak berkehendak untuk membaca sendiri akta tersebut, maka kehendak para pihak tersebut harus dicantumkan pada bagian akhir akta Notaris. Dengan demikian, baik 
akta dibacakan atau tidak dibacakan harus dicantumkan pada bagian akhir akta. Jika hal itu tidak dilakukan, ada aspek formal yang tidak dipenuhinya yang mengakibatkan akta tersebut cacat dari segi bentuk. (2) Pasal 41 yang menunjuk kepada Pasal 39 dan 40 berkaitan dengan aspek subjektif sahnya akta Notaris, yaitu cakap bertindak utuk melakukan suatu perbuatan hukum. Pelanggaran terhadap pasal ini termasuk ke dalam tidak mempunyai pejabat umum yang bersangkutan untuk memahami batasan umum dewasa untuk melakukan suatu perbuatan hukum. (3) Pasal 41 yang menunjuk kepada Pasal 40, khususnya tidak ada hubungan perkawinan dengan Notaris atau hubungan darah dalam garis lurus ke atas atau ke bawah tanpa pembatasan derajat dan garis ke samping sampai dengan derajat ketiga dengan Notaris atau para pihak dan Pasal 52, termasuk ke dalam tidak berwenangnya pejabat umum yang bersangkutan, artinya ada penghalang bagi Notaris untuk menjalankan kewenangannya.

\section{Batasan Akta Notaris yang Batal Demi Hukum}

Akta merupakan alat bukti dari sebuah perjanjian, dimana isi dari akta merupakan implementasi dari apa yang diinginkan oleh para pihak dalam perjanjian. Suatu perjanjian menjadi batal demi hukum apabila tidak memenuhi syarat objektif, yaitu adanya objek tertentu dan kausa yang halal sebagaimana telah diatur dalam ketentuan Pasal 1320

11 R. Subekti, Log.cit., hlm. 48.
KUHPerdata. ${ }^{11}$ Mengenai perjanjian harus mempunyai objek tertentu hal ini ditegaskan dalam ketentuan Pasal 1333 KUHPerdata yang menyebutkan bahwa :

"Suatu perjanjian harus mempunyai sebagai pokok suatu barang yang paling sedikit ditentukan jenisnya. Tidaklah menjadi halangan bahwa jumlah barang tidak tentu, asal saja jumlah itu terkemudian dapat ditentukan atau dihitung."

Sementara itu, mengenai suatu sebab atau hal tertentu yang halal dalam sebuah perjanjia dapat dilihat dalam ketentuan Pasal 1335 KUHPerdata yang menyebutkan bahwa :

"Suatu perjanjian tanpa sebab atau yang telah dibuat karena sesuatu sebab yang palsu atau terlarang, maka perjanjian tersebut tidak mempunyai kekuatan."

Lebih lanjut, ketentuan Pasal 1335 KUHPerdata tesebut di atas dilengkapi oleh ketentuan dalam Pasal 1336 KUHPerdata yang menegaskan bahwa :

"Jika tidak dinyatakan sesuatu sebab, tetapi ada sesuatu sebab yang halal ataupun jika ada sesuatu sebab lain daripada yang dinyatakan persetujuannya namun demikian adalah sah.”

Ketentuan yang tertuang dalam Pasal 1335 dan 1336 KUHPerdata ini telah menegaskan bahwa setiap perjanjian yang dibuat oleh para pihak harus memenuhi unsur atau syarat 
kausa yang halal. Kriteria suatu sebab yang tidak halal atau terlarang telah diatur dalam ketentuan Pasal 1337 KUHPerdata yang mnybutkan bahwa :

"Suatu sebab adalah terlarang, apabila dilarang oleh undangundang, atau apabila berlawanan dengan kesusilaan atau ketertiban umum."

Dengan demikian dapat disimpulkan bahwa suatu perjanjian menjadi batal demi hukum jika perjanjian tersebut memenuhi dua unsur pelanggaran sebagaimana berikut : (1) tidak mempunyai objek tertentu yang dapat ditentukan, dan (2) mempunyai sebab yang dilarang oleh undang-undang atau berlawanan dengan kesusilaan atau ketertiban umum.

Jika melihat ketentuan mengenai akta Notaris yang menjadi batal demi hukum sebagaimana diatur dalam Pasal 84 UUJN, maka kita terlebih dahulu harus mencermati beberapa Pasal yang terkandung dalam ketentuan Pasal 84UUJN, dimanaadabeberapa pasal yang secara tegas menyebutkan bahwa pelanggaran oleh Notaris mengakibatkan akta yang dibuatnya menjadi akta di bawah tangan. Dengan demikian jika melihat isi dari Pasal 84 UUJN, dapat ditafsirkan bahwa ketentuanketentuan yang tidak disebutkan dengan tegas oleh pasal-pasal yang terkandung dalam pasal 84 UUJN sebagai akta yang memiliki kekuatan pembuktian sebagai akta di bawah tangan, maka pasal tersebut termasuk dalam akta Notaris yang batal demi hukum. Melihat ketentuan yang telah diatur dalam Pasal 84 UUJN sebagaimana telah diuraikan di atas, maka dapat kita ambil sebuah kesimpulan bahwa kualifikasi atau batasan yang diberikan Pasal 84 UUJN terhadap akta Notaris yang batal demi hukum meliputi semua kewajiban Notaris yang harus dilaksanakan saat menjalankan jabatannya tanpa ada unsur pelanggaran terhadap objek dan sebab halal dari sebuah perjanjian.

Jika kembali melihat kualifikasi yang telah ditentukan KUHPerdata terkait akta Notaris yang batal demi hukum, sebagaimana diatur dalam ketentuan Pasal 1320, 1335, 1336, dan 1337 KUHPerdata, maka penggunaan istilah "batal demi hukum" untuk akta Notaris karena melanggar ketentuan sebagaimana yang diatur dalam ketentuan Pasal 84 UUJN menjadi tidak tepat. Hal ini dikarenakan ketentuan-ketentuan yang diklasifikasikan sebagai batasan akta Notaris yang batal demi hukum menurut pasal 84 UUJN tidak satupun yang mengandung unsur pelanggaran terhadap objek perjanjian, maupun pelanggaran terhadap sebab halal, sebagaimana diatur dalam KUHPerdata.

\section{Mekanisme Penerapan Sanksi Perdata terhadap Notaris dalam Hal Terjadinya Degradasi Kekuatan Pembuktian dan Pembatalan Akta Notaris}

Sanksi merupakan alat pemaksa selain juga sebagai hukuman dan juga agar para pihak mentaati ketetapan yang ditentukan 
dalam peraturan atau perjanjian. ${ }^{12}$ Sanksi juga diartikan sebagai alat pemaksa sebagai hukuman jika tidak taat kepada perjanjian. ${ }^{13}$ Sementara itu menurut Philipus M. Hadjon, sanksi merupakan alat kekuasaan yang bersifat hukum publik yang digunakan oleh penguasa sebagai reaksi terhadap ketidakpatuhan pada norma hukum administrasi. ${ }^{14}$ Dalam sebuah aturan hukum, pencatuman sanksi merupakan sebuah kewajiban, hal ini dikarenakan jika sebuah peraturan hukum tidak akan dapat ditegakkan jika pada bagian akhir tidak mencantumkan mengenai sanksi. Tidak ada gunanya memberlakukan kaidah-kaidah hukum manakala kaidah-kaidah itu tidak dapat dipaksakan melalui sanksi dan menegakkan kaidah-kaidah yang dimaksudkan secara prosedural (hukum acara). ${ }^{15}$

Sanksi terhadap Notaris diatur pada akhir UUJN, yaitu pada pasal 84 dan 85 UUJN. Dalam UUJN menyebutkan ada 2 (dua) macam sanksi, yaitu sanksi perdata dan sanksi administratif. Sanksi perdata terhadap Notaris berupa penggantian biaya, ganti rugi, dan bunga dimana hal tersebut merupakan akibat yang akan diterima oleh Notaris jika akta otentik yang dibuatnya hanya mempunyai kekuatan pembuktian sebagai akta di bawah tangan atau akta menjadi batal demi hukum. Sanksi keperdataan adalah sanksi yang dijatuhkan terhadap kesalahan yang terjadi karena wanprestasi, atau perbuatan melanggar hukum. Sanksi yang diterapkan adalah berupa penggantian biaya, ganti rugi, dan bunga, dimana semua sanksi tersebut dapat diterapkan kepada Notaris apabila akta yang dibuatnya terdegradasi menjadi akta di bawah tangan atau menjadi batal demi hukum dan merugikan pihak yang berkepentingan dalam akta tersebut.

Akta Notaris yang memiliki kekuatan pembuktian sempurna apabila melanggar ketentuan tertentu sebagaimana telah diatur dalam pasal 84 UUJN akan terdegradasi kekuatan pembuktiannya menjadi akta di bawah tangan. Kedudukan akta Notaris yang kemudian memiliki kekuatan pembuktian sebagai akta di bawah tangan merupakan penilaian atas suatu alat bukti. Akta di bawah tangan memilki kekuatan pembuktian sempurna sebagaimana yang dimiliki akta otentik sepanjang para pihak mengakui isi dari akta tersebut. Dengan demikian, menentukan suatu akta Notaris terdegradasi kekuatan pembuktiannya berada dalam ruang lingkup penilaian suatu alat bukti.

Akta Notaris yang batal demi hukum, maka akta tersebut dianggap tidak pernah ada atau tidak pernah dibuat. Sesuatu yang tidak pernah dibuat tidak dapat dijadikan dasar

12 N.E. Algra, H.R.W.Gokkel dkk, Kamus Istilah Hukum Fockema Andreae, Belanda-Indonesia, Binacipta, Jakarta, 1983, hlm. 496.

13 S.Wojowasito, Kamus Umum Belanda-Indonesia, 1 Ichtiar Baru-Van Hoeve, Jakarta, 1995, hlm. 560.

14 Philipus M. Hadjon, dkk, Pemerintah Menurut Hukum (Wet-en Rechthmatig Bestuur), Cetakan Pertama, Yuridika, Surabaya, 1993, hlm. 245.

15 Philipus M. Hadjon, ibid. 
suatu tuntutan dalam bentuk penggantian biaya, ganti rugi dan bunga. ${ }^{16}$ Dengan demikian seharusnya akta Notaris yang batal demi hukum tidak menimbulkan akibat untuk memberikan penggantian biaya, ganti rugi atau bunga kepada pihak yang tersebut dalam akta.

Penggantian biaya, ganti rugi, serta bunga dapat digugat terhadap Notaris dengan mendasarkan pada suatu hubungan hukum antara Notaris dengan para pihak yang menghadap Notaris. ${ }^{17}$ Hubungan hukum sendiri diartikan sebagai suatu hubungan yang akibatnya diatur oleh hukum. Ketika penghadap datang ke Notaris agar tindakan atau perbuatannya diformulasikan ke dalam akta otentik sesuai dengan kewenangan Notaris, kemudian Notaris membuatkan akta atas permintaan para penghadap tersebut, maka dalam hal ini tindakan tersebut telah memberikan landasan kepada Notaris dan para penghadap sebagai sebuah hubungan hukum. Dengan hubungan hukum seperti itu, maka perlu ditentukan kedudukan hubungan hukum tersebut yang merupakan awal dari tanggunggugat Notaris. ${ }^{18}$

Pasal 84 UUJN yang mengatur mengenai sanksi perdata terhadap Notaris tidak memberikan batasan yang jelas antara kapan akta Notaris terdegradasi kekuatan pembuktiannya menjadi akta di bawah tangan dan kapan akta Notaris menjadi batal demi hukum. Selain itu, pasal 84 UUJN juga tidak memberikan pengaturan mengenai mekanisme penjatuhan sanksi perdata terhadap Notaris yang aktanya terdegradasi kekuatan pembuktiannya menjadi akta di bawah tangan atau menjadi batal demi hukum yang mengakibatkan Notaris berkewajiban memberikan penggantian biaya, ganti rugi, atau bunga terhadap pihak dalam akta yang merasa dirugikan akibat kesalahan Notaris tersebut.

Jika dicermati lebih jauh, substansi Pasal 84 UUJN ini dapat dibandingkan dengan Pasal 60 Peraturan Jabatan Notaris (PJN) yang termuat dalam Reglement op Het Notaris Ambt in Indonesia (Stbl. 1860:3), dimana dalam Pasal 60 PJN disebutkan jika akta yang dibuat di hadapan Notaris tidak memenuhi syarat bentuk dapat dibatalkan di muka pengadilan atau dianggap hanya dapat berlaku sebagai akta yang dibuat di bawah tangan.

Tanpa adanya sebuah pengaturan mengenai mekanisme penerapan sanksi perdata terhadap Notaris dalam ketentuan pasal 84 UUJN, dapat membuka kemungkinan interpretasi bahwa pembuktian terhadap akta Notaris yang terdegradasi kekuatan pembuktiannya menjadi akta di bawah tangan atau batal demi hukum dapat dilakukan secara sepihak tanpa harus melalui proses gugatan ke pengadilan. ${ }^{19}$

16 Komar Andasasmita, Notaris I, Sumur Bandung, Bandung, 1981, hlm. 37.

17 Sjaifurrachman, Op.cit., hlm.196.

18 Marthalena Pohan, Tanggunggugat Advocaat, Dokter, dan Notaris, Bina Ilmu, Surabaya, 1985, hlm. 11.

19 Mario A. Tedja, Teori Kepastian dalam Prespektif Hukum Kontrak, http://mariotedja.blogspot.com/2012/12/ teori-kepastian-dalam-prespektif-hukum.html, diakses 27 Maret 2013 pukul 20.50 WIB. 
Hal demikian tentu sangat bertentangan dengan ketentuan pasal 1877 KUHPerdata yang menyebutkan bahwa :

"Jika seorang memungkiri tulisan atau tanda tangannya, ataupun jika para ahli warisnya atau orang-orang yang mendapat hak daripadanya menerangkan tidak mengakuinya, maka Hakim harus memerintahkan supaya kebenaran dari tulisan atau tanda tangan tersebut diperiksa di muka pengadilan."

Akta Notaris tidak dapat dinilai atau dinyatakan secara langsung secara sepihak memiliki kekuatan pembuktian sebagai akta di bawah tangan atau batal demi hukum oleh para pihak yang namanya tercantum dalam akta atau oleh orang lain yang berkepentingan dalam akta tersebut. Penilaian terhadap akta Notaris yang terdegradasi kekuatan pembuktiannya menjadi akta di bawah tangan atau batal demi hukum karenan melanggar ketentuan pasal 84 UUJN tidak dapat dilakukan oleh Majelis Pengawas, Notaris, atau bahkan oleh para pihak yang namanya tercantum dalam akta Notaris. ${ }^{20}$ Penilaian akta Notaris yang memiliki kekuatan pembuktian sebagai akta di bawah tangan atau batal demi hukum harus melalui proses gugatan ke pengadilan umum untuk membuktikan, apakah akta Notaris melanggar ketentuan-ketentuan dalam pasal 84 UUJN atau tidak.
Jika ada pihak atau penghadap menilai atau menganggap atau mengetahui bahwa akta Notaris melanggar ketentuan-ketentuan dalam pasal 84 UUJN, maka para pihak yang memberikan penilaian tersebut harus dapat membuktikannya melalui proses peradilan (gugatan) dan meminta penggantian biaya, ganti rugi, dan bunga. Dalam gugatan tersebut yang harus dibuktikan oleh penggugat adalah (a) adanya derita kerugian, (b) adanya hubungan kausal antara kerugian yang diderita dan pelanggaran atau kelalaian dari Notaris, (c) bahwa pelanggaran atau kelalaian tersebut disebabkan kesalahan yang dapat dipertanggungjawabkan kepada Notaris yang bersangkutan. ${ }^{21}$

Proses pembuktian seperti ini sejalan dengan teori hukum subjektif, dimana teori ini menetapkan bahwa barang siapa yang mengaku atau mengemukakan suatu hak maka yang bersangkutan harus membuktikannya. Teori hukum subjektif dalam kaitannya dengan proses pembuktian dalam kasus perdata, secara jelas diterapkan dalam ketentuan pasal 1865 KUHPerdata yang menyebutkan bahwa "Setiap orang yang mengaku mempunyai suatu hak, atau menunjuk suatu peristiwa untuk meneguhkan haknya itu atau untuk membantah suatu hak orang lain, wajib membuktikan adanya hak itu atau kejadian yang dikemukakan itu."

20 Sjaifurrachman, Op.cit., hlm. 228.

21 Liliana Tedjosaputro, Etika Profesi Notaris dalam Penegakan Hukum Pidana, Disertasi Universitas Gajah Mada, Yogyakarta, 1994, hlm. 94. 
Dalam Hukum Acara Perdata, pembuktian yang dimaksud berbeda dengan pembuktian dalam ranah hukum pidana. Dalam hukum pidana, sistem pembuktian yang dianut adalah sistem pembuktian stelsel negatif menurut ketentuan undang-undang (negatief weterlijk stelsel) untuk mencari kebenaran materiil (prinsip beyond reasoble doubt). ${ }^{22}$ Sementara dalam hukum acara perdata, kebenaran yang dicarai dan diwujudkan leh hakim cukup berupa kebenaran formil (formeel warheid). ${ }^{23}$ Dalam mencari kebenaran formil, prinsip yang patut dipegang oleh hakim antara lain adalah bahwa hakim bersifat pasif, yaitu tidak diperkenankan untuk mengambil prakarsa aktif untuk menambah atau mengajuan pembuktian yang diperlukan. Hal itu merupakan pilihan hak dari masingmasing pihak. Prinsip lain adalah bahwa putusan berdasarkan pembuktian fakta, yaitu ditolak atau dikabulkannya gugatan harus berdasarkan pembuktian dari fakta-fakta yang diajukan oleh para pihak.

Selanjutnya, atas gugatan pihak yang merasa dirugikan oleh Notaris yang aktanya terdegradasi kekuatan pembuktiannya atau mengalami batal demi hukum karena melanggar ketentuan pasal 84 UUJN, Notaris berhak untuk memberikan perlawanan atau penjelasan. Jika dalam proses peradilan penggugat dapat membuktikan gugatannya, dan pengadilan memutuskan akta Notaris memiliki kekuatan sebagai akta di bawah tangan atau batal demi hukum, maka barulah Hakim dapat membebankan tuntutan penggugat kepada Notaris berupa penggantian biaya, ganti rugi, atau bunga. Demikian pula jika ternyata gugatan tersebut tidak terbukti atau ditolak oleh Hakim, maka tidak menutup kemungkinan Notaris yang sebelumnya digugat mengajukan gugatan kepada para pihak yang sebelumnya telah menggugatnya. Hal ini sebagai upaya untuk mempertahankan hak dan kewajiban Notaris dalam menjalankan tugas jabatannya berkaitan dengan akta yang dibuat di hadapan atau oleh Notaris.

Prosedur sepeti yang dijelaskan di atas harus dilakukan agar tidak terjadi penilaian sepihak atas suatu akta Notaris, hal ini dikarenakan akta Notaris memiliki kekuatan pembuktian yang sempurna, serta dapat dinilai dari aspek lahiriah, formal, dan materiil. Notaris dalam membuat akta atas permintaan para pihak berdasarkan pada tata cara atau prosedur dalam pembuatan akta Notaris sebagaimana telah diatur dalam UUJN. Ketika para penghadap menganggap ada yang tidak benar dalam akta tersebut, akibat melanggar ketentuaan dalam pasal 84 UUJN dan menderita kerugian sebagai akibat langsung dari akta tersebut, maka pihak yang bersangkutan berhak menggugat Notaris

22 Nile K. Rumokoy, Tinjauan Terhadap Asas-Asas Umum Pemerintahan yang Baik dalam Penyelenggaraan Kekuasaan Pemerintahan, http://www.google.co.id/asas kepastian hukum dalam penyelenggaraan pemerintahan yang baik, diakses 11 Maret 2013 pukul 21.00 WIB.

23 Edy Rajo, Pembuktian dalam Hukum Perdata, http://edyrajo.blogspot.com/2013/02/pembuktian-dalamhukum-perdata.html, diakses 23 Juni 2013 pukul 21.50 WIB. 
dan berkewajiban membuktikan bahwa akta Notaris tidak memenuhi aspek lahiriah, formal, dan materiil, serta membuktikan kerugiannya. Dengan demikian, penilaian akta Notaris yang mempunyai kekuatan pembuktian sebagai akta di bawah tangan atau batal demi hukum tidak dari satu pihak saja, tapi harus dilakukan oleh atau melalui dan dibuktikan di pengadilan. ${ }^{24}$

\section{Simpulan}

Batasan akta Notaris yang memiliki kekuatan pembuktian sebagai akta di bawah tangan menurut pasal 84 UUJN adalah melanggar ketentuan pasal 16 ayat (1) huruf 1, pasal 16 ayat (7) dan ayat (8), pasal 41 dengan menunjuk kepada Pasal 39 dan 40, dan melanggar ketentuan pasal 52 UUJN. Sementara itu, batasan akta Notaris yang batal demi hukum menurut ketentuan Pasal 84 UUJN adalah, melanggar kewajiban sebagaimana tersebut dalam Pasal 16 ayat (1) hurufi, pasal 16 ayat (1) hurufk, Pasal 44, Pasal 48, pasal 49, Pasal 50, dan Pasal 51 UUJN. Meskipun Pasal 84 UUJN tidak memberikan mekanisme atau tata cara mengenai penerapan sanksi perdata kepada Notaris dalam hal terjadinya degradasi kekuatan pembuktian dan pembatalan akta Notaris, tidak serta merta Akta Notaris dapat dinilai atau dinyatakan secara langsung secara sepihak memiliki kekuatan pembuktian sebagai akta di bawah tangan atau batal demi hukum oleh para pihak yang namanya tercantum dalam akta atau oleh orang lain yang berkepentingan dalam akta tersebut. Penilaian akta Notaris yang memiliki kekuatan pembuktian sebagai akta di bawah tangan atau batal demi hukum harus melalui proses gugatan ke pengadilan umum untuk membuktikan, apakah akta Notaris melanggar ketentuan-ketentuan dalam pasal 84 UUJN atau tidak.

Penulis mempunyai saran agar dalam rancangan undang-undang Notaris yang baru perlu dilakukan revisi terkait isi pasal 84, khususnya mengenai batasan kapan akta Notaris menjadi akta di bawah tangan dan kapan akta Notaris menjadi batal demi hukum. Sebaiknya ketentuan dalam Pasal 60 Peraturan Jabatan Notaris yang termuat dalam Reglement op Het Notaris Ambt in Indonesia (Stbl. 1860:3) khususnya mengenai mekanisme penerapan sanksi perdata terhadap Notaris diberlakukan kembali di undangundang jabatan Notaris yang akan datang. Hal ini dikarenakan ketentuan masih relevan dan bahkan diperlukan demi kepastian hukum bagi Notaris dan para pihak dalam akta. 


\section{DAFTAR PUSTAKA}

\section{Buku}

Habib Adjie, 2009, Hukum Notaris Indonesia, Refika Aditama, Jakarta.

Habib Adjie, 2011, Kebatalan dan Pembatalan Akta Notaris, refika Aditama, Bandung.

Jazim Hamidi, 2005, Hermeneutika Hukum, UII Press, Yogyakarta.

Jimly Asshiddiqie dan Ali Safa'at, 2006, Teori Hans Kelsen Tentang Hukum,

Setjen dan Kepaniteraan Mahkamah

Konstitusi Republik Indonesia, Jakarta.

Komar Andasasmita, 1981, Notaris I, Sumur

Bandung, Bandung.

Mariam Darus Badrulzaman, 2001, Kompilasi

Hukum Perikatan, Citra Aditya Bakti, Bandung.

Marthalena Pohan, 1985, Tanggunggugat

Advocaat, Dokter, dan Notaris. Bina Ilmu, Surabaya.

Philipus M. Hadjon, 1993, Pemerintah

Menurut Hukum, Yuridika, Surabaya.

R. Subekti, 2001, Hukum Pembuktian,

Pradinya Paramita, Jakarta.

Sjaifurrachaman, 2011 ,

Aspek

Pertanggungjawaban Notaris Dalam

Pembuatan Akta, Mandar Maju,

Bandung.

Sudikno Mertokusumo, 1999, Mengenal

Hukum Suatu Pengantar, Liberty, Yogyakarta.

\section{Disertasi}

Liliana Tedjosaputro, 1994, Etika Profesi Notaris Dalam Penegakan Hukum Pidana, Universitas Gajah Mada.

\section{Internet}

Edy Rajo, Pembuktian Dalam Hukum Perdata, http://edyrajo.blogspot. com/2013/02/pembuktian-dalamhukum-perdata.html.

Mario A. Tedja, Teori Kepastian dalam Prespektif Hukum Kontrak, http:// mariotedja.blogspot.com/2012/12/ teori-kepastian-dalam-prespektifhukum.html.

Nile K. Rumokoy, Tinjauan Terhadap AsasAsas Umum Pemerintahan Yang Baik Dalam Penyelenggaraan Kekuasaan Pemerintahan, http://www.google. co.id/asas kepastian hukum dalam penyelenggaraan pemerintahan yang baik.

\section{Peraturan Perundang-Undangan}

Kitab Undang-undang Hukum Perdata.

Undang-undang Republik Indonesia, tentang Jabatan Notaris

Undang-undang Republik Indonesia Nomor 12 Tahun 2011, tentang Pembentukan Perundang-Undangan, UU No.12 Tahun 2011. 


\section{Kamus}

Kementerian Pendidikan Nasional, 2008,

Kamus Besar Bahasa Indonesia

Pusat Bahasa Edisi Keempat,

Gramedia Pustaka Utama, Jakarta.
N.E. Algra, H.R.W.Gokkel dkk, 1983, Kamus Istilah Hukum Fockema Andreae, Belanda-Indonesia, Binacipta, Jakarta. S.Wojowasito, 1995 Kamus Umum BelandaIndonesia, 1 Ichtiar Baru-Van Hoeve, Jakarta. 